Berti - Logic(s) and paradox

\title{
LOGIC(S) AND PARADOX
}

\section{Marco Berti}

Marco Berti - University of Technology Sydney

Author Biography:

Marco Berti is Senior Lecturer in Management at UTS Business School, University of Technology Sydney. His research focuses on paradox and power, and has been published, among others, in Academy of Management Review, Academy of Management Learning and Education, Management Learning, Organization, Journal of Management Inquiry. 


\section{ABSTRACT:}

This chapter investigates the mutual relationship between logic and paradox, showing that paradox is indispensable to test logic, as well as logic is necessary to extend our understanding of paradox. Firstly, I consider the lesson that organizational theory can draw from formal logic's investigation of semantic and set-theoretic paradoxes. Subsequently, I survey the plural interpretations of the concept of 'logic' in organizational theory (as logic of theory, logic of practice, and institutional logics). I argue that this plurality of meaning is not a source of confusion but offers an opportunity to illustrate different manifestations of, and ways to cope with, organizational paradoxes.

\section{KEYWORDS:}

1. Paradox

2. Logic

3. Institutional logics

4. Practice theory

5. Pragmatic paradox 
"It is always easy to be logical. It is almost impossible to be logical to the bitter end".

(Camus, 1955, p. 8)

\section{INTRODUCTION}

Paradoxes have been explained as fallacies in the construction of logical categories (Whitehead \& Russell, 1962), but also accepted as an unavoidable consequence of logic (Priest, 1979). The philosophical discussion on paradox dates back to the fourth century BC, when Eubulides, a contemporary of Aristotle, offered the first formulation of several logical puzzles, including the famous liar paradox, that have since defied an agreed upon solution (Priest, 2017). The notion of paradox is now well established in organizational studies, where it is employed to account for the apparent absurdities that characterize most workplaces (Hennestad, 1990; Farson, 1996). These organizational paradoxes derive from the existence of persistent, interdependent contradictions that are intrinsic to organizing (Smith \& Lewis, 2011).

This chapter examines the mutual relationship between logic and paradox, showing their interdependence: on the one hand, logic both generates and helps disentangling paradoxes; on the other hand, paradoxes both challenge and reinforce logic, by revealing its limitation. This philosophical investigation can prove useful to advance our understanding of organizational paradoxes, helping to investigate the sources of such interdependent contradictions, explaining why they are so widespread in organizations.

I start by considering how paradoxes are discussed in the context of formal logic, the system of reasoning which is at the basis of traditional scientific inquiry (Lewis, 2000), as this is the field of studies that has been investigating paradoxes for the longest time. In philosophy paradoxes are not considered mere puzzles; rather they have been used to test apparently solid chains of argumentations, strengthening the edifice of formal logic. Indeed, paradoxes have long been employed to reveal and challenge the taken-for-granted assumptions that found conventionally accepted knowledge (Luhmann, 1986). Even if the complexity of the social world far exceeds the rarefied realm of formal logic, organization studies can benefit from a reflection on the logicians' treatments of paradoxes. In particular, I propose to leverage on the multiple meanings of 'logic' that have emerged in the context of Management and Organization Studies: logic of theory versus logic of practice, and singular logic versus plural logics. These alternate definitions of logic can be used to reveal and map different conceptualizations (and manifestations) of organizational paradoxes, and to extend our understanding of their origin.

\section{PARADOXES AND FORMAL LOGIC}

The relationship between logic and paradox is long and multifaceted: it has been said that "logicians... abhor ambiguity but love paradox" (Barwise \& Etchemendy, 1989, p. 3). On the one hand "the logical tradition tries to suppress the paradox" as it threatens to "destroy the telos of thinking" (Luhmann, 1995a, p. 38). On other hand, paradoxes have been a resource for logical inquiry, forming a natural object of philosophical investigation from ancient Greece to contemporary application to system logics and computer science (Schad et al., 2016; Cantini \& Bruni, 2017). 
To better understand the role of paradoxes in the context of logic it is useful to start with some definitions. Logic is "the analysis and appraisal of arguments" (Gensler, 2010, p. 1) and, more specifically "formal logic is primarily concerned with valid inferences-in other words, with inferences in which the logical forms of premises and conclusion force us to accept the latter once we have accepted the former" (Hoyningen-Huene, 2004, pp. 24-25). In a logic perspective a paradox may be defined as "a contradiction that follows correct deduction from consistent premises" (Watzlawick et al., 1967, p. 188). Therefore, paradoxes seem to produce a fracture in the edifice of logic: how can a contradiction derive from correct inferences? Indeed, logicians seem to react in polarized ways in face of paradoxes.

Two major intellectual traditions on the usage of paradox have historically emerged. The "logical" tradition has attempted to suppress paradoxes treating them as breaches to the Aristotelian law of non-contradiction (contradictory propositions cannot be true at the same time). By contrast the "rhetorical tradition" has leveraged on paradoxes to test and reframe taken-for-granted assumptions (Luhmann, 1995a, p. 38). Embracing the etymology of the term, para (contrary to) and doxa (common belief), paradoxes have been used as epistemological tools to complexify our understanding of reality(Tsoukas, 2017). In line with the first perspective, some logician argue that paradoxes do not constitute "veridical sentences", i.e. statement that can be either true or false (Hoyningen-Huene, 2004, p. 16): therefore they cannot be the object of logic analysis, similarly to other assertions that are neither true or false: norms, desires, commands, exclamations, or tautologies. Instead, those embracing the second position treat paradoxes as essential objects of philosophical reflection, raising questions about the nature of truth (Gensler, 2010). From this perspective "the significance of a paradox is never the paradox itself, but what it is a symptom of" (Barwise \& Etchemendy, 1989, p. 4). Inspired by the idea that "in the evolution of real knowledge [...] a contradiction [...] marks the first step in progress towards victory" (Whitehead, 1925, p. 187), the discussion of paradoxes has allowed important advancement in formal logic.

Definitions are central to any form of scientific inquiry (Jensen, 1983), and the first hurdle to be overcome in the study of paradox is the correct usage of the term. In lay language any apparent contradictions is typically labelled 'paradox', and as a consequence different constructs are bundled together (Putnam et al., 2016). Quine (1966) offers a more formal and precise classification, distinguishing real logical paradoxes both from "veridical paradoxes", counterintuitive but correct statement (e.g. the number of birthdays of someone born on a leap day does not correspond to their age), and from "falsidical paradoxes", apparent contradictions emerging from incorrect premises, as the Zeno's paradox of motion, which fallaciously 'proves' the impossibility of movement (Huggett, 2019).

Language plays a central role in creating paradoxes, and formal logic identifies an entire category of unsolvable contradictions, known as semantic paradoxes, which derive from terminological indeterminacy, i.e. the ambiguity or 'fuzziness' of most words (Hyde \& Raffman, 2018). Semantic paradoxes often stem from self-referential definitions, as in the case of the Liar's paradox (e.g. 'this statement is false', or 'I am lying'). Addressing these paradoxes, influential logicians such as Bertrand Russell and Alfred Tarski have proposed that, as a safeguard against logical incoherence, a language must not contain their truth predicate (that is, the affirmation that something is 'true'). This implies that, to avoid circular references, a meta-language must be employed "to ascribe truth or falsity to a statement in a given language" (Gensler, 2010, p. 381). A metalanguage is a higher-level language, "dealing with the structure of the first language and having itself a new structure" (Russell, 1951, p. 
23). When considering the 'I am lying' sentence in this new light, we realize that this apparently simple, three-word sentence actually combines two separate statements, one on the object-level, the other on the metalevel, and these two are saying opposite things, hence the confusion. If we want to preserve meaning factual statements and statements about statements should be kept separate (Watzlawick et al., 1967, p. 193).

Logicians and mathematicians have also identified paradoxes that cannot be ascribed to linguistic inconsistencies, but are intrinsic to logic. These are also labelled antonymies (Kant, 2009 [1781]), or set-theoretic paradoxes. The best known example is the so called Russel's paradox, "the class of all classes which are not members of themselves" (Watzlawick et al., 1967, p. 190): such set is both a member of itself and not a member of itself, violating the principle of non-contradiction, one of the cornerstones of logic. The discussion on how to deal with paradoxes is still ongoing among contemporary logicians (Cantini \& Bruni, 2017). This debate has led to the development of a whole branch of thought, defined paraconsistent logic. Also known as Dialetheism, this approach accepts that at least some contradictions can be 'true' and valid (Priest, 1979; Priest et al., 2018), a position that is also held by various Eastern philosophies (Schad, 2017).

These philosophical reflections on the causes of paradox can be put to use to reflect on the sources of organizational paradoxes, addressing a question that has been frequently neglected by organizational scholarship: why are organizations "rife with paradoxes"(Smith et al., 2017, p. 1)? Or, in other words, what explains the "underlying tensions" (Smith \& Lewis, 2011, p. 382) that organizing invariably generates?

\section{FORMAL LOGIC AND ORGANIZATIONAL PARADOXES}

In a seminal contribution to paradox theory, Poole and van de Ven noted that "paradoxes in management are not, strictly speaking, logical paradoxes" (1989, p. 564). Their argument is that in a social context oppositions are not so clear cut: instead of logical irreconcilability they are characterized by tensions, "stress, anxiety, discomfort, or tightness in making choices" (Putnam et al., 2016, p. 69). The fundamental difference is that, while in formal logic appearances, interpretations, communication biases are inconsistencies to be expunged, from a sociological perspectives they are building blocks of social reality (Berger \& Luckmann, 1967 [1990]).

In organizational theory paradoxes are therefore seen as "contradictory yet interrelated elements... that seem logical in isolation but absurd and irrational when appearing simultaneously" (Lewis, 2000, p. 760 emphasis added). Building on the seminal contribution by Smith and Lewis (2011), various studies have helped articulating the dynamics through which underlying but latent tensions are made salient by conditions of plurality, change, resource scarcity and actors' cognition. Some have focused on the role of paradox mindsets, the capacity to accept and built on contradictions, as a determinant of effective responses to salient paradoxes (Miron-Spektor et al., 2018), while others have highlighted the role of social constructions in determining salience of paradoxes, focusing on managerial decisions (Knight \& Paroutis, 2017), social networks (Keller et al., 2020), micro-practices (Smets et al., 2015; Jarzabkowski \& Lê, 2017), discursive interactions (Tuckermann, 2019). Considering the relationship between latency and saliency helps considering organizational paradoxes as both grounded in systems and materiality (Schad \& Bansal, 2018) and shaped by social production of meaning (Pradies et al., 2020) or by the imposition of impossible challenges (Gaim et al., 
2019). Hahn and Knight (2019) have proposed that latent paradoxes exist in a probabilistic state, and that they are not just 'noticed' by actors, but made concrete and determinate by the existence a sociomaterial "measurement apparatus" (2019, p. 20).

Yet an articulate explanation of the source of the underlying, latent tensions that "inherent in organizational systems" (Smith \& Lewis, 2011, p. 382) is still missing. Explanations based on historically rooted tensions (Engeström \& Sannino, 2011) or coexistence of multiple logics (Jay, 2013; Smith \& Besharov, 2019) apply only to some cases. Two more general explanations attribute organizational paradoxes to inherent systemic complexity (Schad \& Bansal, 2018) or to mental frames (Keller \& Chen, 2017). The most articulate description of how system complexity generates paradoxes is offered by Luhmann (1995b), who shows that attempts to simplify context complexity by means of coding and differentiations operations (for example, creating specialised units to deal with specific environmental requirements) generate contradictions, as they produce internal complexity. A 'psychological' explanation of paradox instead attributes them to human tendency to efficiently categorize phenomena and experiences by resorting to binary oppositions (e.g. cooperate versus compete, or innovate versus preserve) (Keller \& Chen, 2017).

Considering formal logic's investigation of paradox can help us correlating and integrating these interpretations, offering insights on the reasons why organizing and ordering activities inevitably lead to generating potential paradoxes that can then be rendered visible or salient by specific conditions. First, the discussion of semantic paradoxes highlights the role of language ambiguities and uncertainty in producing contradictions both in logic and in social organization. Take the example of the sorites paradox (from the ancient Greek word for heap, soros): if a single grain of sand is not a heap, nor the addition of another single grain of sand is enough to transform a non-heap into a heap, what makes a collection of grains of sand a heap? This semantic paradox draws attention on the consequences of linguistic vagueness on social arrangements. If an individual actor, a technological artefact, or even a single process, does not make an organization, nor the simple addition of another actant or process does: so, when is that we truly have an organization? And to what extent are individual members accountable for organizational deeds?

Logicians have responded to this challenge by endorsing the use of formal languages (such as those of mathematics or of symbolic logic). However, this solution is not available to organizational actors. Even if organizations try to control uncertainty by 'buffering' the technical core from disturbances caused by external agents (Thompson, 1967), ambiguities cannot be eliminated from human interaction. "Any definition can be misunderstood" (Wittgenstein, 1958 § 30), and even an apparently simple question such as 'can you do it?' that might be asked of an employee, incorporates a multiplicity of meanings, such as: 'do you have the skills/knowledge...'; 'do you have the time...'; or 'do you have the authority to do it?'. These misunderstandings are exacerbated by the pursuit of efficiency, which induces to formulate orders and policies as self-explanatory, unambiguous messages, removing space for open dialogue and contestation (Berti \& Simpson, 2020a).

Even the apparently abstract set-theoretic paradoxes (antonymies) have implications for organizations. Organizing aims at ordering efficiently a complex reality (Simon, 1947 [1997]), but "neatly defined distinctions (...) fail when pursued rigorously to the end" (Chia \& Nayak, 2017, p. 130). Paradoxes that derive from vicious circles of logic (for example, by a self-referential proposition) can be avoided, according to some logicians, by setting limits to the use of propositions (Whitehead \& Russell, 1962). Again, this solution is not available to 
modern social actors, since the capacity to order actions and objects according to universal, abstract principles is an essential requirement. Driven by the assumption that "one can, in principle, master all things by calculation" (Weber, 1919 [1946], p. 139), contemporary bureaucratic organizations are founded on a "legal order" based on propositions "combined in a system which is [... free from internal contradictions" (Weber, 1922 [1978], p. 311). Unfortunately, as Camus poetically lamented, our "wild longing for clarity" produces absurdity: attempts at circumventing contradictions by means of meticulous ordering and regulation will generate more contradictions. Consequently, bureaucracies are riddled with paradoxes. Actors subject to rigid regulations will regain discretion by leveraging ambiguity, with the consequence of increasing uncertainty, which triggers further regulation, etcetera (Crozier, 1964). Apparently logical requests sometime result in absurd, 'Catch-22' requirements for individuals (Stohl \& Cheney, 2001; Sayer, 2007; Tye-Williams \& Krone, 2017). Boundaries also become a source of paradox, rather than of clarity (Cooper, 1986). Finally, attempts to reduce complexity through selection and differentiation end up generating new contingencies and differences (Luhmann, 1995b). In other words, it is the delusion of perfect order that exposes us to disorder.

As mentioned before, another strategy has been proposed by formal logic to deal with antonymies: to embrace the 'dialetheia' (i.e. holding opposites truths), accepting that organizing paradoxes cannot be ignored nor 'solved'. This is consistent with the prescriptions of organizational paradox theory. Developing paradoxical frames, defined as "mental templates in which managers recognize and accept the simultaneous existence of contradictory forces" (Smith \& Tushman, 2005, p. 526) is instrumental to accommodate tensions that emerge from contradictory but interrelated organizational requirements. Accepting dialetheia does not only mean acknowledging that opposites are not mutually exclusive and that a 'both/and' approach is possible. It also suggests that logic can be treated as a plural, manifold concept. By exploring the multiple meanings and manifestations of the concept of logic in organization theory, I propose we can further advance our understanding of the sources of organizational paradoxes.

\section{Paradoxes and Logic in Management and Organization theory}

If logic in philosophy is exclusively concerned with the appraisal of arguments' validity, in organizational theory the term 'logic' has had multiple connotations. It is here argued that this plurality of meanings is not a source of confusion; rather, it can be leveraged upon to describe various uses, and manifestations, of organizational paradoxes. In order to relate these different meanings of logic in organizational theory, I employ the tried-and-trusted method of identifying two pairs of contrasting concepts (polarities). Once crossed, these define four distinct quadrants that can be used to plot complex information in a simplified matter. The first duality distinguishes logic of theory and logic of practice, while the second one contrasts singular and plural logics. The purpose of this device is not to pigeonhole fluid phenomena and interdependent concept, but to show that different meanings of 'logic' underpin contrasting, but equally useful, understandings of organizational paradox.

\section{Logic of theory versus Logic of practice}

The distinction between logic of theory and logic of practice derives from alternative onto-epistemological perspectives. Logic of theory assumes that it is possible to formulate an objective, universal and timeless representation of reality, independent from observers, who 
are therefore detached from the world they observe (Sandberg \& Tsoukas, 2011). This standpoint can inform both academic research and practitioners' action. In the case of academics, it is at the basis of a method of theorizing that induces general, abstract principles from empirical observations, producing statements of relations (Bacharach, 1989); these universal rules can then be deductively applied to multiple contexts, showing "how and/or why a phenomenon occurs" (Corley \& Gioia, 2011, p. 12). For practitioners, leads to separate and assign to different actors strategy and implementation, decision and execution, thought and action, and has a corollary the idea that managerial action is reducible to the application of 'scientific' techniques (Bailey \& Ford, 1996).

Against this backdrop, paradox is understood as a challenge, both in the connotation of 'defying' and 'testing' established representations of the world. The transcendence of "ordinary logic" implied by the experience of paradox (Rothenberg, cited in Lewis, 2000, p. 764) does not imply irrationality. Rather, it acknowledges the intrinsic limitation of logic (of Theory), "a language that is universal but not consistent" (Czarniawska, 2001, p. 13). This inconsistency derives from the tension (already discussed above) between the ambition to produce ideal typical, abstract representations and an empirical reality that is complex and fuzzy (Starbuck, 1988). This philosophical issue has very tangible implications: organizing processes generate competing requirements, such as the need to focus on the particular while maintaining a general vision, or the need to change while maintaining consistency, constitute a common challenge for organizations (Smith \& Lewis, 2011; Sheep et al., 2017). A logic of theory perspective highlights the universal nature of these polarities: they are thought to affect (at least as a latent potential) every organization, even if they only become salient when organizational actors 'observe' them (Hahn \& Knight, 2019).

Logic of practice (Sandberg \& Tsoukas, 2011) is grounded in an alternative set of assumptions, which are rooted in Heidegger's philosophy (1927). Refuting that idea that observer and observed can be separated, logic of practice views actors as always situated in a specific time and place, entwined with other individuals and things. In this perspective knowing is an embodied, performative act (Tsoukas, 2017), which enable actors to cope with a specific, and ever transforming, context. When paradoxes are considered in the frame of logic of practice, their processual dimension is highlighted (Cunha \& Putnam, 2019), implying a multiplicity of micro copying activities (Lê \& Bednarek, 2017). Finally, it treats paradoxes not as abstract universals, but as situated, socially constructed phenomena (Putnam et al., 2016). As a consequence, a practice view allows to appreciate the experience of individual actors, who must cope with tensions within the constraints and opportunities afforded by the social setting in which they are embedded (Berti \& Simpson, 2020a).

By situating paradoxes in a social context, a practice theory perspective reveals the role of power in shaping organizational paradoxes. Relations of power, which can be both visible and invisible, and both episodic or systemic (Clegg, 1989; Fleming \& Spicer, 2014) alter knowledge outcomes, so that power shapes truth (Foucault, 1977, 1980). Rather than taking for granted that individuals have full agency in coping with contradictory requirements and attributing their failure to meet the challenge to the lack of an appropriate attitude, this perspective stresses that disempowered actors will often experience paradoxes not as generative opportunities but as paralysing pathologies (Berti \& Simpson, 2020a). 


\section{Single versus plural (institutional) logics}

The second duality contrasting singular logic and plural logics. A 'singular' perspective is funded on the idea that there is only "one right logic" (Shapiro \& Kouri Kissel, 2018), i.e. a unique valid way to the ideal for guiding reasoning and action. A breach of such correct way of thinking will cause incongruities, either in the form of mistake or outright absurdity. A typical embodiment of the such perspective is scientific management (Taylor, 1911), with its aim to identify a 'one best way' to optimise workflows. This understanding is coherent with the view of organizing as rational ordering activity, based on a goal oriented allocation of responsibility and knowledge (Simon, 1947 [1997]).

The assumption of singular logic, typically derives from the existence of a dominant paradigm, a coherent framework of assumptions, methods and standards, that informs research (Kuhn, 1970). Different paradigms are difficult to bridge, because of their "different meta-theoretical assumptions with regard to the nature of science and society" (Burrell \& Morgan, 1979: 24). Not only academics, but also practitioners, can - implicitly or explicitly presume that the logic they follow, shaped by dominant discourses and by cultural assumptions is the only possible one.

Yet, the very assumption of a singular logic is paradoxical: it implies that alternative (albeit aberrant) logics exist. Indeed, organizational paradox theory has drawn attention to the existence of different mindsets that shape the way in which different individuals framed and cope with contradictions. The assumption of the separation of opposites required by Aristotelian logic implies a polarization of the tension ( $\mathrm{Li}, 1998$; $\mathrm{Li}, 2014$ ), leading to an "either/or thinking" (Lewis, 2000, p. 762). If the dominant logical frame is an either/or one, contradictions deriving from inconsistencies are treated as mistakes that need fixing. By contrast, in Eastern philosophies, under the auspices of Taoist logic, "paradox is the norm rather than the exception", and "opposition" is regarded "as empowering" (Schad, 2017, p. 30). In this case paradoxes will be sought and cherished rather than avoided (Li 1998). Yet, even this latter perspective is not truly 'plural', since it still presumes that there is just one best way to deal with complexity (i.e. 'both/anding'), dismissing the possibility to achieve sustainable results otherwise.

In a plural perspective the term logic is less 'muscular': rather than a measure of absolute rationality, it is understood as the outcome of a social construction, historically and contextually grounded in a specific field (Thornton \& Ocasio, 2008). In social sciences the term 'logic' is often substituted by the notion of rationality, rule-bound choices among alternatives of action (Wallace, 1990). As these implicit decision rules can differ, multiple legitimate forms of rationality can co-exist (Weber, 1922 [1978]), imposing different decision rules and priorities to organizational members (Cloutier \& Langley, 2007). These institutional logics are socially constructed sets of practices and assumptions that shape cognition and behaviour within a specific institutional setting (Thornton et al., 2012). They act as "taken-for-granted social prescriptions" (Battilana \& Dorado, 2010, p. 1420), or "rules of the game" (Thornton \& Ocasio, 2008, p. 112), defining goals and expectations and legitimate activities. Institutional logics are not just abstract sets of normative expectations that are unthinkingly complied with; rather, they are enacted in day-to-day activities, and "can be used by actors in a contested environment to influence decisions, justify activities, or advocate for change" (McPherson \& Sauder, 2013, p. 167).

Contemplating plural logics suggests that they can be a major source of tensions (Smets et al., 2015; Stadtler \& Van Wassenhove, 2016). Most organizations are influenced by a 
multitude of competing institutional logics (Thornton \& Ocasio, 2008) because they incorporate different professional groups, pursue disparate objectives and have to negotiate with various stakeholders. The compresence of multiple logics does not per se create paradoxes; these emerge when different logics are both contradictory and core to organizational functioning (Besharov \& Smith, 2014). To cope with the resulting 'hybridity' organizations need to adopt a mix of stable organization features (formal structures, leadership expertise, and stakeholder relationships associated with each of the contrasting logic) and adaptive enactment processes based on paradoxical conceptual frames, that acknowledge the interdependent nature of the contrasting elements of the hybrid (Smith \& Besharov, 2019). Examples of competing logics generating organizational paradoxes include the contrast between collaboration and competition (Stadtler \& Van Wassenhove, 2016); market and community (Smets et al., 2015); family and market (Miller et al., 2011); profit and social purposes (Pache \& Santos, 2010).

\section{A MAP FOR EXPLORING THE RELATIONSHIP BETWEEN LOGICS AND PARADOX}

In order to map the relationship between different conceptualizations of logic in organizational studies, I propose to position them on a diagram that intersects the dualism logic of theory/logic of practice with the dualism singular/plural logic(s), offering a map of the complex relationship between logic and paradox (Fig 1).

\section{Figure 1 Here}

The four ideal-typical 'logical framing of paradox' that result from this diagram are useful to identify alternative interpretations of organizational paradox, that illuminate different sources, empirical manifestation of the phenomenon, and that require distinct coping strategies (Tab.1). It is important to stress that these framing are not to be intended as alternative 'mindsets': they are rather a heuristic tool that can be used to reveal the multiple origins and consequences of the contradictions that characterize organizing.

\section{Table 1 Here}

\section{Singular/logic of theory}

Considering the theory/singular logic quadrant leads to an interpretation of paradox as a 'breach of order'. The correct way to address this disturbance depend on the one logic that is assumed to be correct. Within the frame of logic based on the non-contradiction principle (i.e. an 'either/or' logic), paradox is an inconsistency that must be corrected or ignored, since it can only derive from an incompleteness or ambiguity in representation. Many different behaviours can be associated with this view of paradox, including splitting, repressing or suppressing the tension, focusing on a single element of the paradox, etcetera (Jarzabkowski \& Lê, 2017). Considered in an either/or perspective, dealing with contradictions demands trade-off compromises, sacrificing one area to achieve benefits in another (Byggeth \& Hochschorner, 2006). 
Conversely, if the opposition between alternative polarities is considered from the perspective of a both/and logic, its generative potential, as a source of change and renewal, within a dynamic order can become manifest (Lewis, 2000; Smith \& Lewis, 2011). Seizing this opportunity requires assuming a 'dialethic' mindset, i.e. one that accept and is even invigorated by contradictions (Miron-Spektor et al., 2018). This mindset, allowing a synergetic accommodation of the opposition, can be supported by a "broader system of meanings and social relationships" (Pradies et al., 2020, p. 18), including actors' participation in heterogeneous social networks (Keller et al., 2020). The possibility to transcend paradox, situating contradictory elements in a new "harmonious" relationship (Chen, 2002, p. 183), is also coherent with this perspective. This result can be achieved by reframing the relationship between the opposites in a more complex representation (Bartunek, 1984; Bartunek, 1988; Cuganesan, 2017), or "third vision" (Janssens \& Steyaert, 1999, p. 132).

Ironically, by categorically excluding that a salient tension could be sustainably resolved by resorting to 'defensive' choices (i.e. privileging one pole over the other) also paradox theory (Smith \& Lewis, 2011) implicitly betrays dialethic principles. Despite its emphasis on 'both-anding', it is still funded on the assumption that only one logic can to represent reality accurately. Therefore, within a 'single logic of theory' framework, the source of paradox is a conceptual clash between incompatible positions, a contradiction that must be resolved, by making the right choice, based on exclusion of legitimate alternatives.

\section{Plural/logic of theory}

Accepting that the several legitimate logics and rationalities are coexisting in organizations allows to enrich our understanding of organizational paradoxes. Multiple, interrelated prescriptions on how to interpret and function in social situations are a prime source of tensions which need to be navigated by practitioners and scholars alike (Greenwood et al., 2011). In a 'logic of theory' perspective, these represent alternative representations of reality, informed by different rationalities and setting different priorities. The focus of inquiry is on the strategic efforts of management to accommodate these competing prescriptions. The central recommendation is to embrace hybridity by incorporating meaning and practices aligned with contrasting logics, rather than emphasising some elements at the expense of others, thus mixing rigidity and flexibility (Smets \& Jarzabkowski, 2013; Smets et al., 2015; Smith \& Besharov, 2019). Another possibility is to adopt separation strategies, such as spatialization (assigning to different actors or unit responsibility to focus on different 'poles') or temporalization (focusing at times on one and at times on another of the contradictory requirements) (Poole \& van de Ven, 1989).

Having to deal with multiple contrasting institutional logic should not be considered just a challenge, since it also presents the opportunity to generate "novel combinations of capital, tacit knowledge, and regimes of justification" (Jay, 2013, p. 138) driving innovation and development. An additional advantage of considering the interrelation of plural logics is to 'qualify' the injunction to adopt a both/and approach, aware that it could lead to a Panglossian view of tensions, according to which it is always possible to find a 'win-win' accommodation. For instance Hahn et al. (2010) have shown that this is not the case for some trade-offs typical of corporate social and environmental sustainability.

This framing sees the origin of organizational paradoxes in the need to comply with contrasting social norms and expectations while maintaining a strategic and operational consistency. This is a universal challenge, which becomes particularly salient for organizations 
which must grapple with multiple institutional logics, Examples are social enterprises (Smith \& Besharov, 2019), art organizations (Glynn \& Lounsbury, 2005), professional associations (Goodrick \& Reay, 2011), public sector organizations (Denis et al., 2015).

\section{Singular/logic of practice}

Considering paradox in the perspective of 'singular' logic of practice helps situating them in a specific context, and instantiated in everyday actions and communications (Lê \& Bednarek, 2017), also drawing attention to the role of power. In an organizational context where actors possess a modicum of agency, and the existence of contradictions is widely acknowledged, forms of practical coping will be developed to navigate paradoxes. This can include informal but consistent patterns of social interaction (Smets et al., 2015), as well as talk and humour (Jarzabkowski \& Lê, 2017). Such informal, embodied practices can become embodied into organizational routines and procedures (Jarzabkowski et al., 2013). Even 'transcendence' of paradox is possible; however, if in a 'singular/logic of theory' setting reframing is cognitive operation, in this practice logic setting transcendence is achieved via rhetorical practices that help actors reformulating their collective understanding of the situation (Abdallah et al., 2011; Bednarek et al., 2017).

When even this limited agency is removed and tasks are assumed to be unambiguous, disempowered actors might end up in dire straits. Staff members will be expected to comply to directives, taking for granted that a correct execution will produce the desired results, and autonomy will be curtailed, being viewed as an undesirable source of uncertainty. Nevertheless, communication ambiguities and unpredictable events will present them with contradictory demands. Deprived both of agency and of the capacity to discuss their predicament, they will be trapped in a paralysing pragmatic paradoxes (Watzlawick et al., 1967; Berti \& Simpson, 2020a). These can take the form of 'double binds', when subjected to direct, self-contradictory orders (e.g. 'Try something new but without making mistakes') that cannot be discussed (Bateson et al., 1963; Tracy, 2004). They can also manifest as 'paradoxical predictions' (Watzlawick, 1965), when actors are subject to manipulations that constraints their capacity for critical judgment, for instance when they must accept the implementation of 'best practices' while knowing they will be counterproductive in their specific context (Gondo \& Amis, 2013). Another possibility is ' Catch-22' situations, where contradictory but indisputable rules expose actors to formally legitimate, yet incompatible, demands (Stohl \& Cheney, 2001; Currie et al., 2009), a condition that typically manifest in Kafkaesque bureaucracies (Warner, 2007; McCabe, 2014; Clegg et al., 2016). Finally, pragmatic paradoxes can be embedded in identity and meaning shaping discourses (Willmott, 1993, 2013), for instance when technology enabled flexible work arrangement, promoted as ways to increase individual autonomy become vehicles for exploitation (Mazmanian et al., 2013), or when female managers are socially expected to perform at the same time masculine and feminine roles (Gherardi, 1994; Wendt, 1995; Oakley, 2000).

In both cases, these practical paradoxes originate from individual participation in social structures, with the unavoidable existence of power differentials. Typically, they derive from contradictory requests that must be simultaneously complied with; when actors maintain a modicum of agency, they will be able to devise practical ways to work through the contradiction. If instead they are locked into a rigid relationship, that deprive them of the possibility to legitimately choose any acceptable course of action (including questioning the 'absurd' request they received), they will be either paralysed or forced to adopt dysfunctional behaviours, such as ritualism, withdrawal or paranoia (Tracy, 2004). 


\section{Plural/logic of practice}

A plural/practice theory framework, acknowledges both the presence of inescapable institutional complexity and forestages the role of power relationships. This perspective challenges the idea that it is always possible to preserve current order by 'managing' tensions. On the contrary, it focuses on the transformational potential of tensions, drawing attention of a dialectic perspective on tensions (Mumby, 2005; Hargrave \& Van de Ven, 2017; Farjoun, 2019). Dialectics examines how social processes emerge through a conflict between alternative poles that it is not resolved by the victory of one pole over another, but that implies a mutual transformation (Clegg \& Cunha, 2017). The 'synthesis' that is thus produced is not an endgame; rather it is bound to generate further tensions, in a continuous process (Putnam et al., 2016).

Dialectical transformation is not achieved through 'acceptance' or accommodation, but through conflict (Hargrave \& Van de Ven, 2017). This conflict does not have to be destructive: opposite poles are connected, interwoven and co-emergent (Putnam et al., 2016). Also vicious circles deriving from 'mismanaged' tensions can fuel a dialectical conflict that is essential to bring change to an oppressive system (Clegg \& Cunha, 2017). An example is offered by the gender identity struggles in organizations (Putnam \& Ashcraft, 2017): resistance to oppressive gender roles can paradoxically reinforce them; and yet this lack of success reinvigorate necessary resistance. In practice, this dialectic perspective is particularly useful to consider the political dynamics deriving from the need to manage contradictions. For instance, a Head of Operations is likely to take a different stance from the Head of R\&D in relation to the best way to navigate the exploration/exploitation tensions, and their relative capacity to influence strategic decisions will be determinant of the way in which their organization will find a synthesis between the two.

Within this framework, paradoxes originate from the existence of alternative and incompatible ways of 'ordering' and regulating, which find legitimation in different worldviews and systems of interests, and that can mobilize sufficient resources and influence to support their claims. In such perspective contradictions do not persist in clearly recognizable state, but are continuously transforming, and cannot be disentangled from their context (Hargrave, 2020). Because of the political incompatibility between the different logics, oppositions cannot be harmoniously combined, but will transform each other through a dialectic conflict, in a process that Hegel described as a combination of destruction and combination, forming a new concept that is richer than the preceding ones since it includes both (Hegel, 1812 [2010]). The emergent synthesis is not necessarily synergetic, since one position can have more influence than the other(s) in shaping the synthesis. Dealing with this process of 'sublation' (the assimilation of a smaller entity into a larger one) does not require the creation of workable certainty based on assimilating the opposites (Lüscher \& Lewis, 2008), but implies accepting the existence of never ending conflicts caused by divergent interests, desires and identities, using this as a way to fuel continuous learning (Hargrave, 2020).

\section{DISCUSSION AND CONCLUSION}

Considering organizations in a recursive perspective (Hernes \& Bakken, 2003), highlighting their paradoxical nature (Luhmann, 2018) can confront us with mindboggling 
complexity. Instead of recurring to an excessive simplification that risks to decontextualize, abstract, and reify paradox (Cunha \& Putnam, 2019) it is important to balance wild complexity and tamed but actionable simplification (Fairhurst, 2019). In this chapter we have seen that a holistic 'logic(s) of paradox' can help put in relationship multiple varieties of paradox, extending the limit of restrictive theorizations that are implicitly bounded by tacit assumptions. In particular, we have seen how different conceptualization of organizational tensions are rooted in different understandings of what constitute 'logic'. Neither of these views has more truth value than the others; it is simply useful to illustrate different phenomena and to articulate different critical interpretation of their implications.

Achieving and maintain a 'paradox mindset' can be as challenging for paradox scholars as it is for practitioners. Pressure for providing a theoretical account that is both parsimonious, unambiguous and coherent (Bacharach, 1989) leads us to purge our models of excessive complexity (Eisenhardt, 1989), but this comes at the risk of renouncing to necessary variety. By embracing a plural understanding of logic, we can understand that paradoxes can be both phenomena and representation, both obstacles to be removed and opportunities to be seized, both challenges to logic, and tools to expand it. Acknowledging logic not as an individual but as a plural concept helps making sense of apparently inconsistent conceptualizations of organizational tensions.

This is not just a theoretical concern, but it has practical implications. Different ways of framing the relationship between logic and paradox, based upon alternative idea of what is logic, suggest different ways to deal with organizational tensions. Thinking of paradoxes within a logic of theory perspective can stimulate the search of integrative solutions, but implies a conservative attitude, since its focus on balancing tension implies maintaining the status quo. Yet, in face of entrenched injustices (such as those caused by systemic racism or gender inequality), an appeal to resort to synergistic solutions can lead to the preservation of an unfair 'equilibrium' (Berti \& Simpson, 2020b). On the other hand, an exclusive focus on conflictual solutions risks missing genuine opportunities for a creative reconciliation of divergent interests. Besides, a focus on situated, embodied logic of practice is useful to reveal the importance of emotions and practical coping in dealing with paradox, while considering logic of theory helps considering structural and strategic opportunities for accommodating contradictory demands.

In sum, there are multiple possible ways to construe, interpret, and respond to the interdependent contradictions that pervade organizational life. Theoretically, the proposed model offers an opportunity to map the different epistemological assumptions that underpin alternative ways to study contradictions: as trade-offs, 'generative' paradoxes, pragmatic paradoxes and dialectics. From a practice perspective, it stimulates both researchers and practitioners to go beyond 'one best way' approaches when dealing with organizational tensions. Each representation of contradiction is unavoidably incomplete, but can be used for specific purposes, or pursuing the objectives and interests of different stakeholders.

The relationship between logic and paradox is indeed full with tensions, but it is from such tensions that novel ways of thinking and acting stem. As Kierkegaard eloquently expressed, "the paradox is the source of the thinker's passion, and the thinker without a paradox is like a lover without feeling" (1843 [1985], p. 46). 
Berti - Logic(s) and paradox

\section{References}

Abdallah, C., Denis, J.-L., \& Langley, A. (2011). Having your cake and eating it too : Discourses of transcendence and their role in organizational change dynamics. Journal of Organizational Change Management, 24(3).

Bacharach, S. B. (1989). Organizational theories: some criteria for evaluation. Academy of Management Review, 14(4), 496-515.

Bailey, J., \& Ford, C. (1996). Management as Science versus Management as Practice in Postgraduate Business Education. Business Strategy Review, 7, 7-12.

Bartunek, J. M. (1984). Changing interpretive schemes and organizational restructuring: The example of a religious order. Administrative Science Quarterly, 355-372.

Bartunek, J. M. (1988). The Dynamics of Reframing. In K. S. Cameron \& R. E. Quinn (Eds.), Paradox and transformation: Toward a theory of change in Organization and Management (pp. 137162). Cambridge, MA: Ballinger Publishing Company.

Barwise, J., \& Etchemendy, J. (1989). The Liar : An Essay on Truth and Circularity. Oxford, UK: Oxford University Press.

Bateson, G., Jackson, D. D., Haley, J., \& Weakland, J. H. (1963). A note on the double bind. Family Process, 2(1), 154-161.

Battilana, J., \& Dorado, S. (2010). Building sustainable hybrid organizations: The case of commercial microfinance organizations. Academy of Management Journal, 53(6), 1419-1440.

Bednarek, R., Paroutis, S., \& Sillince, J. (2017). Transcendence through Rhetorical Practices: Responding to Paradox in the Science Sector. Organization Studies, 38(1), 77-101.

Berger, P. L., \& Luckmann, T. (1967 [1990]). The social construction of reality : a treatise in the sociology of knowledge. New York: Anchor Books.

Berti, M., \& Simpson, A. V. (2020a). The Dark Side of Organizational Paradoxes: The Dynamics of Disempowerment. Academy of Management Review(Published Online: 26 Nov 2019. DOI: 10.5465/amr.2017.0208).

Berti, M., \& Simpson, A. V. (2020b). On the Practicality of Resisting Pragmatic Paradoxes. Academy of Management Review(Published Online).

Besharov, M. L., \& Smith, W. K. (2014). Multiple institutional logics in organizations: Explaining their varied nature and implications. Academy of Management Review, 39(3), 364-381.

Byggeth, S., \& Hochschorner, E. (2006). Handling trade-offs in ecodesign tools for sustainable product development and procurement. Journal of Cleaner Production, 14(15-16), 1420-1430.

Camus, A. (1955). The myth of Sisyphus, and other essays. New York, NY: Alfred A. Knopf.

Cantini, A., \& Bruni, R. (2017). Paradoxes and Contemporary Logic The Stanford Encyclopedia of Philosophy (Fall 2017 ed.).

Chen, M.-J. (2002). Transcending paradox: The Chinese "middle way" perspective. Asia Pacific Journal of Management, 19(2), 179-199.

Chia, R., \& Nayak, A. (2017). Circumventing The Logic And Limit Of Representation: Otherness In East-West Approaches To Paradox. In W. K. Smith, M. W. Lewis, P. Jarzabkowski \& A. Langley (Eds.), The Oxford Handbook of Organizational Paradox (pp. 125-140). Oxford: Oxford University Press.

Clegg, S. R. (1989). Frameworks of power. London, UK: SAGE.

Clegg, S. R., \& Cunha, M. P. (2017). Organizational Dialectics. In W. K. Smith, M. W. Lewis, P. Jarzabkowski \& A. Langley (Eds.), The Oxford Handbook of Organizational Paradox (pp. 105124). Oxford: Oxford University Press.

Clegg, S. R., Cunha, M. P., Munro, I., Rego, A., \& de Sousa, M. O. (2016). Kafkaesque power and bureaucracy. Journal of Political Power, 9(2), 157-181.

Cloutier, C., \& Langley, A. (2007). Competing rationalities in organizations: A theoretical and methodological overview. Cahiers de recherche du GéPS, 1(3), 1-35.

Cooper, R. (1986). Organization/Disorganization. Social Science Information, 25(2), 299-335. 
Corley, K. G., \& Gioia, D. A. (2011). Building theory about theory building: what constitutes a theoretical contribution? Academy of Management Review, 36(1), 12-32.

Crozier, M. (1964). The bureaucratic phenomenon. Chicago, IL: University of Chicago Press.

Cuganesan, S. (2017). Identity Paradoxes: How Senior Managers and Employees Negotiate Similarity and Distinctiveness Tensions over Time. Organization Studies, 38(3-4), 489-511.

Cunha, M. P., \& Putnam, L. L. (2019). Paradox theory and the paradox of success. Strategic Organization, 17(1), 95-106.

Currie, G., Lockett, A., \& Suhomlinova, O. (2009). The institutionalization of distributed leadership: A 'Catch-22' in English public services. Human Relations, 62(11), 1735-1761.

Czarniawska, B. (2001). Having hope in paralogy. Human Relations, 54(1), 13-21.

Denis, J. L., Ferlie, E., \& Van Gestel, N. (2015). Understanding hybridity in public organizations. Public Administration, 93(2), 273-289.

Eisenhardt, K. M. (1989). Building Theories from Case Study Research. Academy of Management Review, 14, 532-550.

Engeström, Y., \& Sannino, A. (2011). Discursive manifestations of contradictions in organizational change efforts: A methodological framework. Journal of Organizational Change Management, 24(3), 368-387.

Fairhurst, G. T. (2019). Reflections: Return Paradox to the Wild? Paradox Interventions and Their Implications. Journal of Change Management, 19(1), 6-22.

Farjoun, M. (2019). Strategy and dialectics: Rejuvenating a long-standing relationship. Strategic Organization, 17(1), 133-144.

Farson, R. (1996). Management of the Absurd. New York, NY: Simon and Schuster.

Fleming, P., \& Spicer, A. (2014). Power in management and organization science. The Academy of Management Annals, 8(1), 237-298.

Foucault, M. (1977). Discipline and punish: the birth of the prison. New York, NY: Vintage Books.

Foucault, M. (1980). Truth and Power. In C. Gordon (Ed.), Power/Knowledge: Selected Interviews and Other Writings 1972-1977 (pp. 109-133). New York, NY: Random House.

Gaim, M., Clegg, S. R., \& Cunha, M. P. (2019). The False Mastery of Paradox: The Case of Volkswagen Emissions Scandal. Paper presented at the Academy of Management Proceedings.

Gensler, H. J. (2010). Introduction to Logic. Abingdon, UK: Taylor \& Francis Group.

Gherardi, S. (1994). The gender we think, the gender we do in our everyday organizational lives. Human Relations, 47(6), 591-610.

Glynn, M. A., \& Lounsbury, M. (2005). From the critics' corner: Logic blending, discursive change and authenticity in a cultural production system. Journal of Management Studies, 42(5), 10311055.

Gondo, M. B., \& Amis, J. M. (2013). Variations in practice adoption: The roles of conscious reflection and discourse. Academy of Management Review, 38(2), 229-247.

Goodrick, E., \& Reay, T. (2011). Constellations of institutional logics: Changes in the professional work of pharmacists. Work and Occupations, 38(3), 372-416.

Greenwood, R., Raynard, M., Kodeih, F., Micelotta, E. R., \& Lounsbury, M. (2011). Institutional Complexity and Organizational Responses. Academy of Management Annals, 5(1), 317-371.

Hahn, T., Figge, F., Pinkse, J., \& Preuss, L. (2010). Trade-offs in corporate sustainability: you can't have your cake and eat it. Business Strategy and the Environment, 19(4), 217-229.

Hahn, T., \& Knight, E. (2019). The Ontology of Organizational Paradox: A Quantum Approach. Academy of Management Review, Published Online: 30 Sep 2019.

Hargrave, T. J. (2020). The Paradox Perspective and the Dialectics of Contradictions Research. In M. S. Poole \& A. H. Van de Ven (Eds.), The Oxford Handbook of Organizational Change and Innovation. Oxford, UK: Oxford University Press.

Hargrave, T. J., \& Van de Ven, A. H. (2017). Integrating Dialectical and Paradox Perspectives on Managing Contradictions in Organizations. Organization Studies, 38(3-4), 319-339.

Hegel, G. W. F. (1812 [2010]). The science of logic. Cambridge, UK: Cambridge University Press. 
Heidegger, M. (1927). Being and Time (J. Stambaugh, Trans.). New York, NY: State Universtity of New York Press.

Hennestad, B. W. (1990). The symbolic impact of double bind leadership: Double bind and the dynamics of organizational culture. Journal of Management Studies, 27(3), 265-280.

Hernes, T., \& Bakken, T. (2003). Implications of self-reference: Niklas Luhmann's autopoiesis and organization theory. Organization Studies, 24(9), 1511-1535.

Hoyningen-Huene, P. (2004). Formal logic: a philosophical approach. Pittsburgh, Pennsylvania: University of Pittsburgh Press.

Huggett, N. (2019). Zeno's Paradoxes. In E. N. Zalta (Ed.), The Stanford Encyclopedia of Philosophy (Winter 2019 ed.). Retrieved from https://plato.stanford.edu/archives/win2019/entries/paradox-zeno.

Hyde, D., \& Raffman, D. (2018). Sorites Paradox. In E. N. Zalta (Ed.), The Stanford Encyclopedia of Philosophy (Summer 2018 ed.).

Janssens, M., \& Steyaert, C. (1999). The world in two and a third way out? The concept of duality in organization theory and practice. Scandinavian Journal of Management, 15(2), 121-139.

Jarzabkowski, P., Lê, J. K., \& Van de Ven, A. H. (2013). Responding to competing strategic demands: How organizing, belonging, and performing paradoxes coevolve. Strategic Organization, 11(3), 245-280.

Jarzabkowski, P. A., \& Lê, J. K. (2017). We Have To Do This and That? You Must be Joking: Constructing and Responding to Paradox Through Humor. Organization Studies, 38(3-4), 433462.

Jay, J. (2013). Navigating Paradox As A Mechanism Of Change And Innovation In Hybrid Organizations. Academy of Management Journal, 56(1), 137-159.

Jensen, M. C. (1983). Organization theory and methodology. Accounting review, 319-339.

Kant, I. (2009 [1781]). The Critique of Pure Reason (J. M. D. Meiklejohn, Trans.). Auckland: The Floating Press.

Keller, J., \& Chen, E. W. (2017). A Road Map of the Paradoxical Mind. In W. K. Smith, M. W. Lewis, P. Jarzabkowski \& A. Langley (Eds.), The Oxford Handbook of Organizational Paradox (pp. 66-86). Oxford: Oxford University Press.

Keller, J., Wong, S.-S., \& Liou, S. (2020). How social networks facilitate collective responses to organizational paradoxes. Human Relations, 73(3), 401-428.

Kierkegaard, S. (1843 [1985]). Philosophical Fragments, Johannes Climacus. Princeton, NJ: Princeton University Press.

Knight, E., \& Paroutis, S. (2017). Becoming Salient: The TMT Leader's Role in Shaping the Interpretive Context of Paradoxical Tensions. Organization Studies, 38(3-4), 403-432.

Kuhn, T. S. (1970). The structure of scientific revolutions (2nd edition ed.). Chicago, IL: University of Chicago Press.

Lê, J. K., \& Bednarek, R. (2017). Paradox in Everyday Practice. In W. K. Smith, M. W. Lewis, P. Jarzabkowski \& A. Langley (Eds.), The Oxford Handbook of Organizational Paradox (pp. 490509). Oxford: Oxford University Press.

Lewis, M. W. (2000). Exploring paradox: Toward a more comprehensive guide. Academy of Management Review, 25(4), 760-776.

Li, P. P. (1998). Towards a geocentric framework of organizational form: A holistic, dynamic and paradoxical approach. Organization Studies, 19(5), 829-861.

$\mathrm{Li}, \mathrm{X}$. (2014). Can Yin-Yang Guide Chinese Indigenous Management Research? Management and Organization Review, 10(1), 7-27.

Luhmann, N. (1986). The autopoiesis of social systems. In F. Geyer \& J. van der Zouwen (Eds.), Sociocybernetic paradoxes (Vol. 6, pp. 172-192). London SAGE.

Luhmann, N. (1995a). The paradoxy of observing systems. Cultural critique(31), 37-55.

Luhmann, N. (1995b). Social systems. Stanford, CA: Stanford University Press.

Luhmann, N. (2018). Organization and decision. Cambridge, UK: Cambridge University Press. 
Lüscher, L. S., \& Lewis, M. W. (2008). Organizational Change And Managerial Sensemaking: Working Through Paradox. Academy of Management Journal, 51(2), 221-240.

Mazmanian, M., Orlikowski, W. J., \& Yates, J. (2013). The autonomy paradox: The implications of mobile email devices for knowledge professionals. Organization Science, 24(5), 1337-1357.

McCabe, D. (2014). Light in the darkness? Managers in the back office of a Kafkaesque bank. Organization Studies, 35(2), 255-278.

McPherson, C. M., \& Sauder, M. (2013). Logics in action: Managing institutional complexity in a drug court. Administrative Science Quarterly, 58(2), 165-196.

Miller, D., Le Breton-Miller, I., \& Lester, R. H. (2011). Family and lone founder ownership and strategic behaviour: Social context, identity, and institutional logics. Journal of Management Studies, 48(1), 1-25.

Miron-Spektor, E., Ingram, A., Keller, J., Smith, W. K., \& Lewis, M. W. (2018). Microfoundations of Organizational Paradox: The Problem Is How We Think about the Problem. Academy of Management Journal, 61(1), 26-45.

Mumby, D. K. (2005). Theorizing Resistance in Organization Studies: A Dialectical Approach. Management Communication Quarterly, 19(1), 19-44.

Oakley, J. G. (2000). Gender-based barriers to senior management positions: Understanding the scarcity of female CEOs. Journal of Business Ethics, 27(4), 321-334.

Pache, A.-C., \& Santos, F. (2010). When worlds collide: The internal dynamics of organizational responses to conflicting institutional demands. Academy of Management Review, 35(3), 455476.

Poole, M. S., \& van de Ven, A. H. (1989). Using Paradox to Build Management and Organization Theories. Academy of Management Review, 14(4), 562-578.

Pradies, C., Tunarosa, A., Lewis, M. W., \& Courtois, J. (2020). From Vicious to Virtuous Paradox Dynamics: The Social-symbolic Work of Supporting Actors. Organization Studies, 0170840620907200.

Priest, G. (1979). The logic of paradox. Journal of Philosophical Logic, 8(1), 219-241.

Priest, G. (2017, AUGUST 18TH 2017). Eubulides and his paradoxes. Retrieved from https://blog.oup.com/2017/08/eubulides-paradoxes-philosophy/

Priest, G., Berto, F., \& Weber, Z. (2018). Dialetheism The Stanford Encyclopedia of Philosophy (Fall 2018 ed.).

Putnam, L. L., \& Ashcraft, K. L. (2017). Gender and Organizational Paradox. In W. K. Smith, M. W. Lewis, P. Jarzabkowski \& A. Langley (Eds.), The Oxford Handbook of Organizational Paradox (pp. 331-352). Oxford: Oxford University Press.

Putnam, L. L., Fairhurst, G. T., \& Banghart, S. (2016). Contradictions, Dialectics, and Paradoxes in Organizations: A Constitutive Approach. Academy of Management Annals, 10(1), 65-171.

Quine, W. V. (1966). The ways of paradox. New York, NY: Random House.

Russell, B. (1951). Tractatus Logico-Philosophicus. New York, NY: Humanities Press.

Sandberg, J., \& Tsoukas, H. (2011). Grasping the logic of practice: theorizing through practical rationality. Academy of Management Review, 36, 338.

Sayer, A. (2007). Dignity at Work: Broadening the Agenda. Organization, 14(4), 565-581.

Schad, J. (2017). Ad Fontes. Philosophical Foundations of Paradox Research. In W. K. Smith, M. W. Lewis, P. Jarzabkowski \& A. Langley (Eds.), The Oxford Handbook of Organizational Paradox (pp. 27-47). Oxford, UK: Oxford University Press.

Schad, J., \& Bansal, P. (2018). Seeing the Forest and the Trees: How a Systems Perspective Informs Paradox Research. Journal of Management Studies, 55(8), 1490-1506.

Schad, J., Lewis, M. W., Raisch, S., \& Smith, W. K. (2016). Paradox Research in Management Science: Looking Back to Move Forward. Academy of Management Annals, 10(1), 5-64.

Shapiro, S., \& Kouri Kissel, T. (2018). Classical logic The Stanford Encyclopedia of Philosophy (Spring 2018 ed.). 
Sheep, M. L., Fairhurst, G. T., \& Khazanchi, S. (2017). Knots in the discourse of innovation: Investigating multiple tensions in a reacquired spin-off. Organization Studies, 38(3-4), 463-488.

Simon, H. A. (1947 [1997]). Administrative behavior: a study of decision- making processes in administrative organization (4th edition ed.). New York, NY: Macmillan.

Smets, M., \& Jarzabkowski, P. (2013). Reconstructing institutional complexity in practice: A relational model of institutional work and complexity. Human Relations, 66(10), 1279-1309.

Smets, M., Jarzabkowski, P., Burke, G. T., \& Spee, P. (2015). Reinsurance Trading in Lloyd's of London: Balancing Conflicting-Yet-Complementary Logics in Practice. Academy of Management Journal, 58(3), 932.

Smith, W. K., \& Besharov, M. L. (2019). Bowing before Dual Gods: How Structured Flexibility Sustains Organizational Hybridity. Administrative Science Quarterly, 64(1), 1-44.

Smith, W. K., \& Lewis, M. W. (2011). Toward a theory of paradox: A dynamic equilibrium model of organizing. Academy of Management Review, 36(2), 381-403.

Smith, W. K., Lewis, M. W., Jarzabkowski, P., \& Langley, A. (2017). Introduction. The Paradoxes of Paradox. In W. K. Smith, M. W. Lewis, P. Jarzabkowski \& A. Langley (Eds.), The Oxford Handbook of Organizational Paradox (pp. 1-24). Oxford: Oxford University Press.

Smith, W. K., \& Tushman, M. L. (2005). Managing strategic contradictions: A top management model for managing innovation streams. Organization Science, 16(5), 522-536.

Stadtler, L., \& Van Wassenhove, L. N. (2016). Coopetition as a Paradox: Integrative Approaches in a Multi-Company, Cross-Sector Partnership. Organization Studies, 37(5), 655-685.

Starbuck, W. H. (1988). Surmounting our human limitations. In K. S. Cameron \& R. E. Quinn (Eds.), Paradox and transformation: Toward a theory of change in Organization and Management (pp. 65-80). Cambridge, MA: Ballinger Publishing Company.

Stohl, C., \& Cheney, G. (2001). Participatory processes/paradoxical practices communication and the dilemmas of organizational democracy. Management Communication Quarterly, 14(3), 349407.

Taylor, F. W. (1911). The principles of scientific management. New Haven, CT Yale ITS Academic Media \& Technology.

Thompson, J. D. (1967). Organizations in action: social science bases of administrative theory. New York, NY: McGraw-Hill.

Thornton, P. H., \& Ocasio, W. (2008). Institutional logics. In R. Greenwood, C. Oliver, T. B. Lawrence \& R. E. Meyer (Eds.), The SAGE Handbook of Organizational Institutionalism (pp. 99-128). London, UK: SAGE.

Thornton, P. H., Ocasio, W., \& Lounsbury, M. (2012). The institutional logics perspective: A new approach to culture, structure, and process. Oxford, UK: Oxford University Press.

Tracy, S. J. (2004). Dialectic, contradiction, or double bind? Analyzing and theorizing employee reactions to organizational tension. Journal of Applied Communication Research, 32(2), 119146.

Tsoukas, H. (2017). Don't Simplify, Complexify: From Disjunctive to Conjunctive Theorizing in Organization and Management Studies. Journal of Management Studies, 54(2), 132-153.

Tuckermann, H. (2019). Visibilizing and Invisibilizing Paradox: A process study of interactions in a hospital executive board. Organization Studies, 40(12), 1851-1872.

Tye-Williams, S., \& Krone, K. J. (2017). Identifying and re-imagining the paradox of workplace bullying advice. Journal of Applied Communication Research, 45(2), 218-235.

Wallace, W. (1990). Rationality, human nature, and society in Weber's theory. Theory and society, 19(2), 199-223.

Warner, M. (2007). Kafka, Weber and organization theory. Human Relations, 60(7), 1019-1038.

Watzlawick, P. (1965). Paradoxical predictions. Psychiatry, 28(4), 368.

Watzlawick, P., Jackson, D. D., \& Bavelas, J. B. (1967). Pragmatics of human communication: a study of interactional patterns, pathologies, and paradoxes. New York, NY: Norton. 
Berti - Logic(s) and paradox

Weber, M. (1919 [1946]). Science as a Vocation. In H. H. Gerth \& W. C. Mills (Eds.), From Max Weber: Essays in Sociology (pp. 129-156). New York, NY: Oxford University Press.

Weber, M. (1922 [1978]). Economy and society: an outline of interpretive sociology. Berkeley, CA: University of California Press.

Wendt, R. F. (1995). Women in positions of service: The politicized body. Communication Studies, 46(3-4), 276-296.

Whitehead, A. N. (1925). Science and the modern world. New York, NY: The Free Press.

Whitehead, A. N., \& Russell, B. (1962). Principia mathematica. Cambridge, UK: Cambridge University Press.

Willmott, H. (1993). Strength Is Ignorance; Slavery Is Freedom: Managing Culture In Modern Organizations. Journal of Management Studies, 30(4), 515.

Willmott, H. (2013). 'The Substitution of One Piece of Nonsense for Another': Reflections on Resistance, Gaming, and Subjugation. Journal of Management Studies, 50(3), 443-473.

Wittgenstein, L. (1958). Philosophical investigations (G. E. M. Anscombe, Trans.). Oxford, UK: Blackwell. 
Fig.1 A map of the relationship between logic and paradox

\section{Logic of theory}

(abstract, timeless, ideal)

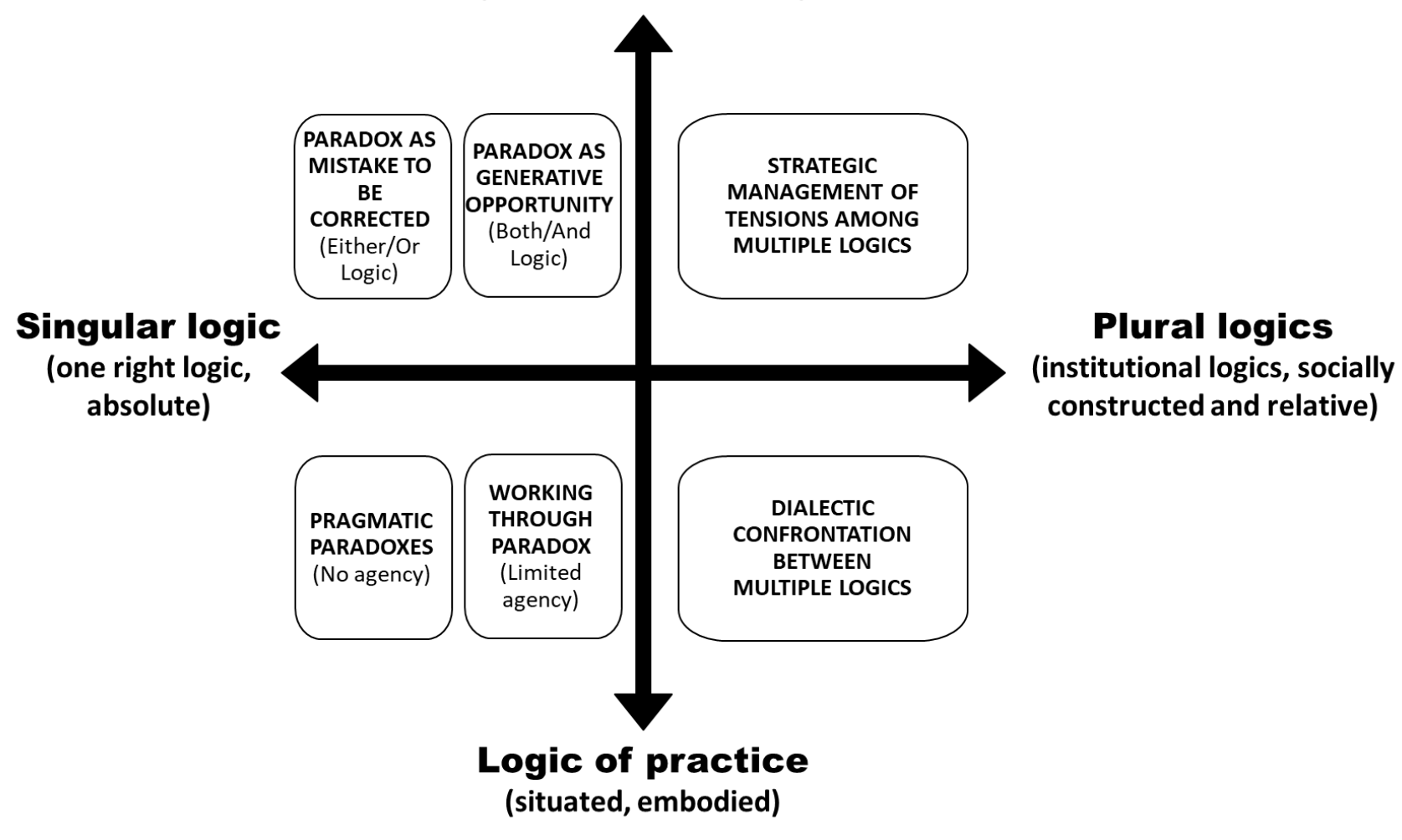


Tab.1 Different understanding of organizational paradox

\begin{tabular}{|c|c|c|c|c|c|c|}
\hline Logic framing & \multicolumn{2}{|c|}{$\begin{array}{l}\text { Logic of theory + } \\
\text { Single logic }\end{array}$} & $\begin{array}{c}\text { Logic of theory }+ \\
\text { Plural (institutional) logics }\end{array}$ & \multicolumn{2}{|c|}{$\begin{array}{l}\text { Logic of practice }+ \\
\text { Single logic }\end{array}$} & $\begin{array}{c}\text { Logic of practice }+ \\
\text { Plural (institutional) logics }\end{array}$ \\
\hline $\begin{array}{l}\text { Definition of } \\
\text { logic }\end{array}$ & \multicolumn{2}{|c|}{$\begin{array}{l}\text { Timeless, universal rationality } \\
\text { principles }\end{array}$} & $\begin{array}{l}\text { Coherent sets of action guiding } \\
\text { ideas (that can be inspired to } \\
\text { different principles) }\end{array}$ & \multicolumn{2}{|c|}{$\begin{array}{l}\text { Situated knowing-in-action } \\
\text { (implying power relations }\end{array}$} & $\begin{array}{l}\text { Socially constructed set of } \\
\text { practices and assumptions } \\
\text { shaping cognition and action } \\
\text { (implying power relations) }\end{array}$ \\
\hline $\begin{array}{l}\text { Interpretation } \\
\text { of Paradox }\end{array}$ & $\begin{array}{l}\text { EITHER/OR LOGIC } \\
\text { Challenge to } \\
\text { logic (to be } \\
\text { removed or } \\
\text { discarded) }\end{array}$ & $\begin{array}{l}\text { BOTH/AND LOGIC } \\
\text { Opportunity } \\
\text { to learn, } \\
\text { expanding } \\
\text { boundaries of } \\
\text { 'common } \\
\text { sense' }\end{array}$ & $\begin{array}{l}\text { Tensions between contrasting } \\
\text { but interdependent logics that } \\
\text { can be made to coexist }\end{array}$ & $\begin{array}{l}\quad \text { EITHER/OR } \\
\quad \text { LOGIC: } \\
\text { Pragmatic } \\
\text { paradox: } \\
\text { Pathological } \\
\text { experience } \\
\text { caused by lack } \\
\text { of agency in } \\
\text { dealing with } \\
\text { contradictions }\end{array}$ & $\begin{array}{l}\text { BOTH/AND LOGIC } \\
\text { A set of } \\
\text { contrasting } \\
\text { requirements } \\
\text { that must be } \\
\text { 'worked } \\
\text { through' }\end{array}$ & $\begin{array}{l}\text { Conflictual confrontation } \\
\text { between incompatible logics } \\
\text { that can only momentarily } \\
\text { accommodated in a synthesis, } \\
\text { which is eventually bound to } \\
\text { generate further transformative } \\
\text { tensions }\end{array}$ \\
\hline $\begin{array}{l}\text { Source of } \\
\text { paradox }\end{array}$ & \multicolumn{2}{|c|}{$\begin{array}{l}\text { Conceptual clash between } \\
\text { incompatible positions }\end{array}$} & $\begin{array}{l}\text { Existence of multiple, legitimate } \\
\text { social prescriptions that impose } \\
\text { different requirements }\end{array}$ & \multicolumn{2}{|c|}{$\begin{array}{l}\text { Power differentials and } \\
\text { contextual conditions }\end{array}$} & $\begin{array}{c}\text { Groups who have different } \\
\text { worldviews and interest }\end{array}$ \\
\hline $\begin{array}{l}\text { Dealing with } \\
\text { paradox }\end{array}$ & $\begin{array}{l}\text { EITHER/OR LOGIC } \\
\text { Remove / } \\
\text { suppress } \\
\text { contradiction }\end{array}$ & $\begin{array}{l}\text { BOTH/AND LOGIC } \\
\text { Embrace } \\
\text { tension (or } \\
\text { transcend it } \\
\text { through } \\
\text { reframing) }\end{array}$ & $\begin{array}{l}\text { Create workable certainty by } \\
\text { segregating logics (spatially or } \\
\text { temporally) or by oscillating } \\
\text { between them }\end{array}$ & $\begin{array}{l}\quad \text { NO AGENCY } \\
\text { Remove } \\
\text { oppressive } \\
\text { conditions } \\
\text { that block } \\
\text { agency }\end{array}$ & $\begin{array}{l}\text { LIMITED AGENCY } \\
\text { Cope with } \\
\text { paradoxes by } \\
\text { means of } \\
\text { micro- } \\
\text { practices }\end{array}$ & $\begin{array}{l}\text { Dialectical approaches: } \\
\text { temporary synthesis emergent } \\
\text { from an ongoing conflict } \\
\text { between different positions }\end{array}$ \\
\hline
\end{tabular}

